\title{
Landslide Vulnerability Zone by Weights of Evidence Model using Remote Sensing and GIS, in Kodaikanal Taluk (Tamil nadu, India)
}

\author{
C. Sivakami \\ Research Scholar \\ Department of Futures Studies, \\ Madurai Kamaraj University
}

\author{
Dr. R. Rajkumar \\ Assistant Professor, \\ Department of Futures Studies, \\ Madurai Kamaraj University
}

\begin{abstract}
Incidences of landslides are common in India. According to Geological Survey of India approximately 0.49 million $\mathrm{km}^{2}$ or $15 \%$ of land area of the country is vulnerable to landslide hazard of which, 0.098 million $\mathrm{km}^{2}$ is located in the north eastern region and the rest $80 \%$ is spread over Himalayas, Nilgiris, Ranchi Plateau and Eastern and Western Ghats (GSI, 2006). The area selected for the study, Kodaikanal taluk is located within the high landslide prone zone, where debris slides, soil slips and rock slides are a major threat for the population living in this area. The present study is the assessment of landslide vulnerability using weights-of-evidence model in Kodaikanal Taluk, Tamil Nadu. In the first stage, landslide locations were identified in the study area from interpretation of high resolution of cartosat data and Google maps, and field surveys. In the second stage, ten data layers are exploited to detect the most vulnerable areas. These factors are TIN, Aspect, Slope, Geomorphology, Land use, Soil, Distance from Roads, Distance from Lineament, Distance from Streams, Rainfall. Next, landslide vulnerable areas were analyzed using the weights-of-evidence model and mapped using landslide conditioning factors.
\end{abstract}

Key Words:- Remote Sensing, GIS, Weights of evidence, Landslide, Kodaikanal Taluk.

\section{INTRODUCTION}

Landslide is a "mass wasting" which denotes any down slope movement of soil and rock under the direct influence of gravity and a disaster that can potentially affect the general quality of life in very many ways. These are complex phenomena, whose time-space distribution results from an interaction of numerous factors such as geological, geomorphological, physical, and human (Varnes, 1978; Crozier, 1986; Cruden and Varnes, 1996).

The devastating effect of Landslide causing irrevocable loss of property of billions of dollars and terminating the invaluable life of loss of thousands of people and cattle as well and injuring are equal number every year makes 'Landslide' in Natural systems are of the most fearful 'Natural Hazards' at global level (Crozier and Glade, 2005). Chung et. al. (1995) make a pointed observation that the worst affected are the developing countries where in occur $95 \%$ of the of the landslides causing an annual loss of $0.5 \%$ gross national products.

The International Landslide Centre of the University of Durham recorded in 2007 that the most seriously affected country was China with 695 landslide-induced deaths, followed by Indonesia (465), India (352), Nepal (168), Bangladesh (150) and Vietnam (130). $89.6 \%$ of the fatalities worldwide were caused by landslides triggered by intense and/or prolonged precipitation. Other triggering processes were construction (mostly undercutting of slopes) (3.4\%), mining and quarrying $(1.8 \%)$ and earthquakes $(0.7 \%)$, while no cause would be identified for $3.4 \%$ of the landslides (Petley, 2008).

\section{STUDY AREA}

The Palani Hills are an Eastward spur of the Western Ghats with a maximum East-West length of $65 \mathrm{~km}$., and a North-South width of $40 \mathrm{~km}$ with a total area of 2064sq.km, Kodaikanal located at Latitude $10^{\circ} 13^{\circ} \mathrm{N}$, Longitude $77^{\circ} 32^{\circ} \mathrm{E}$ is situated in Palani hills and Kodaikanal Taluk is spread over 1050 sq.km . The foothills to $800 \mathrm{~m}$ consist of thorn forest at the lower range and then dry deciduous forest typical of Peninsular India. Sub-montane evergreen forest accompanied by shrub savannah can be seen up to $1600 \mathrm{~m}$. From $1600 \mathrm{~m}$ to $2000 \mathrm{~m}$, the outer montane slopes are characterized by grassland savannah and Shola forests. The upper part of the hills is undulating plateau interspersed with occasional peaks rising to c. $2,500 \mathrm{~m}$. (Area $385 \mathrm{sq}$. $\mathrm{km}$, average altitude $2,200 \mathrm{~m}$ ). The upper montane

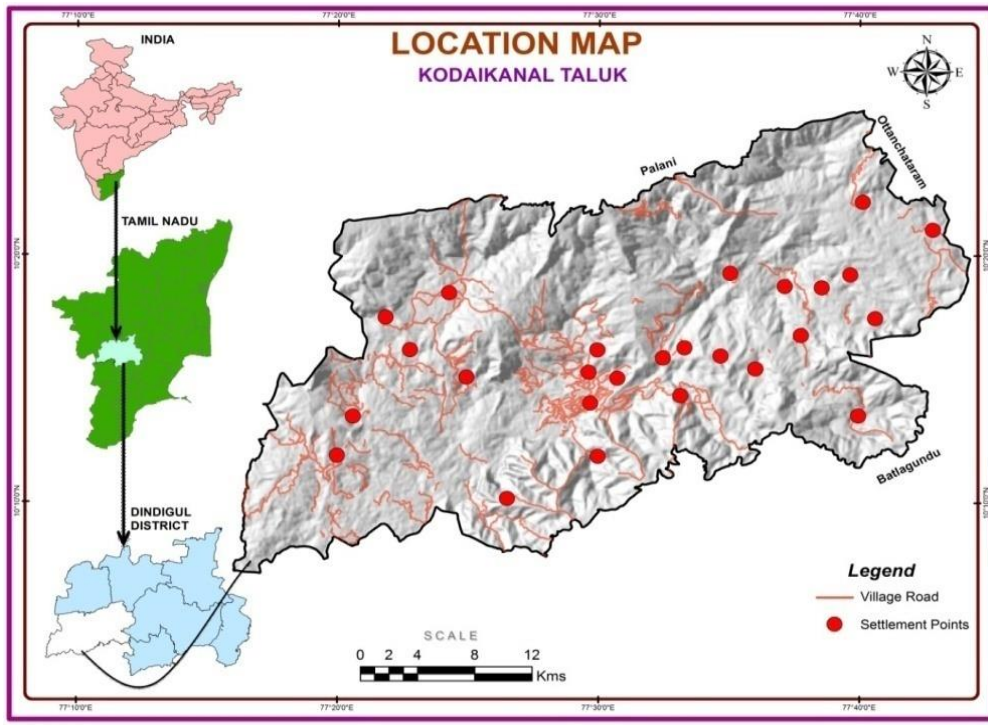


grasslands are interspersed with Shola forests. NilgiriTahr, HemitragusHylocrius, the state animal of Tamil Nadu can be seen in the upper reaches.

\section{MATRIALS AND METHOD}

The studies cited above have been used for WoE objectives and expert- informed subjective methods. The study began with the preparation of landslides inventory map based extends field work, a previous inventory map and satellite images .Furthermore the following seven possible landslide causing layers. The methods identified for the present study are Weights of Evidence (WoE) with the following parameters.

Rain Fall,Slop,Aspect,Elevation,Road,Soil,Drainage,Lineaments,Geomorphology,Land use/Land cover. were analyzed for landslide susceptibility mapping using Weights of Evidence (WoE). Weights of Evidence (WoE) is based on the observed associations between allocation of landslides and each associated factors of landslide occurrence to display the correlation between landslide locations and the parameters controlling landslide occurrence in the area (Lee, 2005).

CARTOSAT(2005) 5.3m resolution, IRS P6 LISS-III (2005) 30m resolution and IRS LISS-IV (2009)5.8 m resolution satellite data products were used as the primary data sources for the present study, collected from National Remote Sensing Agency. Survey of India topographical maps bearing serial numbers 58F 7, 8, 11\&12 1:50,000 scale published in 1969 and 1:25000 scale published in 1994 were used to extract base map features.

\section{LANDSLIDE INVENTORY MAP}

Landslide inventory mapping is the systematic mapping of existing landslides in a region using different techniques such as field survey, air photo/satellite image interpretation, and literature search for historical landslide records. A landslide inventory map provides the spatial distribution of locations of existing landslides. The landslides in the study area were determined by comprehensive field surveys. The landslides which are currently indefinite in characteristics and boundaries were identified using old dated satellite images. As a result, the satellite images were very useful in determination of landslides inventory map (Yalcin and Bulut, 2007). In this study, the susceptibility mapping started with the preparation of an inventory map of 213 (total pixel 4095) landslides from field studies, a previous inventory map, and satellite image analyses from cartosat image.

\section{Weighting of Geomorphology}

Geomorphology is considered as an important factor closely related to landslide occurrence because geomorphological units are created on the integration of the topological characteristics, Geological structures, Geotectonic movements, and morphometries. Geomorphology map for Kodaikanal was collected from SOI at scale 1:50, 000. The Kodaikanal is characterized by Colluvial fills, Bajadas, Deeply Dissected Defection Slope, Less Dissected Plateau, Moderately Dissected Plateau, Pediments, Valley fills and others. Colluvial fills forms thirty five percent of the watershed . Next to it valley fills occupies twenty one percent of the Kodaikanal.

\section{Weighting of Slope}

The slope of the study area ranges from $0^{\circ}$ to $>50^{\circ}$. In general, the steeper the slope, the easier it is for gravity to initiate a landslide. Slopes are classified into six classes according to the gradients that represent terrain morphology such as gently sloping (0$\left.10^{\circ}\right)$, undulating $\left(10-20^{\circ}\right)$, moderately

\begin{tabular}{|l|r|r|r|r|r|r|r|}
\hline $\begin{array}{l}\text { SLOPE } \\
\text { (degree) }\end{array}$ & \multicolumn{1}{|c|}{ NPX1 } & NPX2 & NPX3 & \multicolumn{1}{|c|}{ NPX4 } & W+ & W- & \multicolumn{1}{|c|}{ C } \\
\hline $0-10$ & 255 & 3840 & 280058 & 863102 & 0.2542 & 1.242 & -0.9878 \\
\hline $10-20$ & 907 & 3188 & 307362 & 835798 & 0.8238 & 1.0648 & -0.241 \\
\hline $20-30$ & 1963 & 2132 & 289904 & 853256 & 1.8902 & 0.6975 & 1.1927 \\
\hline $30-40$ & 736 & 3359 & 192315 & 950845 & 1.0684 & 0.9862 & 0.0822 \\
\hline $40-50$ & 194 & 3901 & 50689 & 1092471 & 1.0684 & 0.9968 & 0.0716 \\
\hline$>50$ & 40 & 4055 & 22832 & 1120328 & 0.4891 & 1.0104 & -0.5213 \\
\hline
\end{tabular}

steep $\left(20-30^{\circ}\right)$, steep $\left(30-40^{\circ}\right)$ and very steep $\left(40^{\circ}-50^{\circ}\right)$ and $\left(>50^{\circ}\right)$ Slope angle has a positive effect in the range between $20-50^{\circ}$ based on the positive weighted contrasts. Slope range in class $20^{\circ}-30$ has the most significant spatial association with landslide occurrence.

\section{Weighting of Elevation}

Altitude or elevation is another frequently used conditioning factor for landslide susceptibility analysis. In the present study, the DEM of the study was obtained from topographic maps in 1:50,000 scale with a contour

\begin{tabular}{|l|l|l|l|l|l|l|l|}
\hline ELEVATION & NPX1 & NPX2 & NPX3 & NPX4 & W+ & W- & C \\
\hline $0-500$ & 359 & 3736 & 103528 & 1039632 & 0.968 & 1.0032 & -0.0352 \\
\hline $500-1000$ & 1004 & 3091 & 165494 & 977666 & 1.6936 & 0.8826 & 0.811 \\
\hline $1000-1500$ & 1589 & 2506 & 359212 & 783948 & 1.2349 & 0.8924 & 0.3425 \\
\hline $1500-2000$ & 1016 & 3079 & 239815 & 903345 & 1.1827 & 0.9515 & 0.2312 \\
\hline$>2000$ & 127 & 3968 & 275111 & 868049 & 0.1289 & 1.2761 & -1.1472 \\
\hline
\end{tabular}
interval of $20 \mathrm{~m}$. The elevation of the study area ranges from 500 to $>2000 \mathrm{~m}$. The elevation values were divided into five categories by using an interval of 500m. Elevations $0-500 \mathrm{~m}$ display some negativities association with landslides. The elevation between 500 and 2,000 $\mathrm{m}$ shows a positive association with landslide occurrence. 


\section{Weighting of Aspect}

Aspect is the as horizontal direction to which a mountain or hill slope faces. Which is expressed clockwise, from 0 to 360 degree. In terms of aspect, flat or non-orientated areas have a negative spatial association with landslide occurrence. In other landslide susceptibility assessments (Abdallah, Chorowicz, Bou Kheir, \& Khawlie, 2005; Lee \& Dan, 2005; Lee

\begin{tabular}{|l|l|l|l|l|l|l|l|}
\hline ASPECT & NPX1 & NPX2 & NPX3 & NPX4 & W+ & W- & C \\
\hline Flat & 15 & 4080 & 115755 & 1027405 & 0.0362 & 1.1086 & -1.0724 \\
\hline North & 418 & 3677 & 159017 & 984143 & 0.4273 & 1.043 & -0.3092 \\
\hline Northeast & 295 & 3800 & 108922 & 1034238 & 0.6878 & 1.0257 & -0.2696 \\
\hline East & 634 & 3461 & 103872 & 1039288 & 1.7039 & 0.9296 & 0.7743 \\
\hline Southeast & 337 & 3758 & 151624 & 151624 & 0.6205 & 6.919 & -6.2985 \\
\hline South & 660 & 3435 & 149775 & 993385 & 1.2301 & 0.9653 & 0.2648 \\
\hline Southwest & 640 & 3455 & 111945 & 1031215 & 1.596 & 0.9353 & 0.6607 \\
\hline West & 801 & 3294 & 121079 & 1022081 & 1.8468 & 0.8997 & 0.9471 \\
\hline Northwest & 295 & 3800 & 121171 & 1021989 & 0.6796 & 1.038 & -0.3583 \\
\hline
\end{tabular}
and Talib, 2005) that have investigated aspect, south-facing slopes were found to be most susceptible to landslides. ). Aspects are grouped into 9 classes such as Flat, North, Northeast, East, Southeast, South, Southwest, West, and Northwest.

\section{Weighting of Land use/Land cover}

Land use is the factors related to the effects caused by human activities on landslide occurrence. The study area is covered mainly by forest and waste lands, a lesser extent of grasslands and residential areas mainly in the form of

\begin{tabular}{|l|r|r|r|r|r|r|r|}
\hline LANDUSE/ & & & & & & & \\
LANDCOVER & NPX1 & NPX2 & NPX3 & NPX4 & W+ & W- & C \\
\hline Wastelands & 679 & 3416 & 115593 & 1027567 & 1.6398 & 0.928 & 0.7118 \\
\hline Agriculture land & 611 & 3484 & 274950 & 868210 & 0.6204 & 1.1202 & -0.4999 \\
\hline Builtup & 249 & 3846 & 7722 & 1135438 & 9.0017 & 0.9456 & 8.0561 \\
\hline Forest & 2556 & 1539 & 742887 & 400273 & 0.9605 & 0.5175 & 0.443 \\
\hline Water bodies & 0 & 4095 & 2008 & 1141152 & 0 & 1.0018 & -1.0018 \\
\hline
\end{tabular}
small settlements occupy the study area. By using IRS images, the land use map of the study area was produced and then boundaries were determined in conformity with field visit. In terms of land cover, land cover classes showed Agriculture land and Water bodies in negative weighted contrasts. Built-up land, Waste land and Forest showed the positive contrast value.

\section{Weighting of Streams}

Many of the landslides in hills occur by the erosion associated with drainage. The hilly area is drained by perennial and nonperennial streams; it flows in the Northern part of the study area. The study area depicts dendritic drainage pattern, which is the most common, and looks like the

\begin{tabular}{|l|r|r|r|r|r|r|r|}
\hline STREAM(m) & NPX1 & \multicolumn{1}{|c|}{ NPX2 } & \multicolumn{1}{l|}{ NPX3 } & \multicolumn{1}{l|}{ NPX4 } & W+ & \multicolumn{1}{l|}{ W- } & \multicolumn{1}{l|}{ C } \\
\hline $0-50$ & 1323 & 2772 & 317515 & 825645 & 1.1632 & 0.9372 & 0.2259 \\
\hline $50-100$ & 881 & 3214 & 253593 & 889567 & 0.9698 & 1.0086 & -0.0388 \\
\hline $100-150$ & 890 & 3205 & 286811 & 856349 & 0.8663 & 1.0448 & -0.1785 \\
\hline $150-200$ & 506 & 3589 & 138165 & 1004995 & 1.0224 & 0.9969 & 0.0254 \\
\hline $200-250$ & 304 & 3791 & 78662 & 1064498 & 1.0789 & 0.9942 & 0.0847 \\
\hline$>250$ & 191 & 3904 & 68414 & 1074746 & 0.7794 & 1.014 & -0.2347 \\
\hline
\end{tabular}

branching pattern of tree roots. Proximity to drainage is derived from drainage map with buffer zones on either side of the drainage lines. It is categorized into six classes (in meters) $-0-50 ; 50-100 ; 100-150 ; 150-200 ; 200-250$ and more than 250 (Table 4.19). As higher stream buffer negative is $\mathrm{W}+$ their relation to the occurrence of landslides is not clear .

\section{Weighting of Road}

One of the controlling factors for the stability of slopes is road construction activity. The Ghats road may represent a barrier or a corridor for water flow, a break in slope gradient, or, in any case, may tempt instability and

\begin{tabular}{|l|l|l|l|l|l|l|l|}
\hline LINEAMENT & NPX1 & NPX2 & NPX3 & NPX4 & W+ & W- & C \\
\hline $0-100$ & 169 & 3926 & 47625 & 1095535 & 0.9906 & 1.0004 & 0.9906 \\
\hline $100-200$ & 74 & 4021 & 53716 & 1089444 & 0.3846 & 1.0303 & -0.6458 \\
\hline $200-300$ & 67 & 4028 & 55993 & 1087167 & 0.334 & 1.0343 & -0.7003 \\
\hline $300-400$ & 79 & 4016 & 56544 & 1086616 & 0.39 & 1.0317 & -0.6417 \\
\hline $400-500$ & 183 & 3912 & 56429 & 1086731 & 0.9053 & 1.0049 & -0.0996 \\
\hline$>500$ & 3523 & 572 & 872853 & 270307 & 1.1267 & 0.5907 & 0.536 \\
\hline
\end{tabular}

slope failure mechanisms. The widening of the road is a possible triggering factor and source of landslide vulnerability. The distance from the road is computed as the minimum distance between each of the cells and the nearest road represented in vector format. The distance to roads is calculated in meters and divided into six classes such as $0-100 \mathrm{~m}, 100-200 \mathrm{~m}, 200$ $300 \mathrm{~m}, 300-400 \mathrm{~m}, 400-500 \mathrm{~m}$, and $>500 \mathrm{~m}$. Distance from road between $0-500 \mathrm{~m}$ displayed a positive contrast value, while distance $>500 \mathrm{~m}$ showed a negative contrast value. The road between $0-100 \mathrm{~m}$ shows a positive association with landslide occurrence. To classify road network proximity, buffer analysis was applied. This study uses multiplied distance.

\section{Weighting of Lineament}

The lineament was extracted from IRS images. Proximity (buffers) to these structures increases the likelihood of occurrence of landslides as selective erosion, and movement of water along structural planes promotes such phenomena (Lee 2007; Pradhan et

\begin{tabular}{|l|r|r|r|r|r|r|r|}
\hline ROAD(m) & \multicolumn{1}{|c|}{ NPX1 } & \multicolumn{1}{|c|}{ NPX2 } & NPX3 & NPX4 & W+ & W- & C \\
\hline $0-100$ & 1165 & 2930 & 39892 & 1103268 & 8.1525 & 0.7414 & 7.4112 \\
\hline $100-200$ & 536 & 3559 & 36210 & 1106950 & 4.1323 & 0.8975 & 3.2347 \\
\hline $200-300$ & 449 & 3646 & 33802 & 1109358 & 3.7081 & 0.9175 & 2.7907 \\
\hline $300-400$ & 420 & 3675 & 32756 & 1110404 & 3.5794 & 0.9239 & 2.6555 \\
\hline $400-500$ & 239 & 3856 & 32307 & 1110853 & 2.0652 & 0.969 & 1.0961 \\
\hline$>500$ & 1286 & 2809 & 968193 & 174967 & 0.3708 & 4.4818 & -4.111 \\
\hline
\end{tabular}


al. 2009; Pradhan 2010). The buffer of the lineament as follows (in meters) - 0-100m, 100-200m, 200-300m, 300-400m,400$500 \mathrm{~m}$, and $>500 \mathrm{~m}$ (Table 4.21). Distance from fault between 100-500 m displayed a negative contrast value, while distance $>$ $500 \mathrm{~m}$ showed a positive contrast value. Results show that lineament between $0-100 \mathrm{~m}$ have a strong relationship with landslide occurrence.

\section{Weighting of Rainfall}

The mean annual precipitation in Kodaikanal ranges from $132 \mathrm{~mm}$ over lowlands to $1238 \mathrm{~mm}$ over highlands. Rainfall distribution map was produced using an empirical equation that relates altitude to the mean annual rainfall over

\begin{tabular}{|l|l|l|l|l|l|l|l|}
\hline RAINFALL & NPX1 & NPX2 & NPX3 & NPX4 & W+ & W- & C \\
\hline $0-300$ & 0 & 4095 & 1574 & 1141586 & 0 & 1.0014 & -1.0014 \\
\hline $300-600$ & 13 & 4082 & 78774 & 1064386 & 0.0461 & 1.0706 & -1.0245 \\
\hline $600-900$ & 299 & 3796 & 355302 & 787858 & 0.2349 & 1.345 & -1.1101 \\
\hline $900-1200$ & 1449 & 2646 & 309871 & 833289 & 1.3054 & 0.8864 & 0.419 \\
\hline$>1200$ & 2334 & 1761 & 397639 & 745521 & 1.6386 & 0.6594 & 0.9792 \\
\hline
\end{tabular}
the Kodaikanal Taluk. Rainfall value from 900 to $1200,>1200$ showed a positive contrast value and others showed a negative contrast value. The highest contrast value determined in the Rainfall classes was class rank $>1200$. The second highest was class 900-1200.

\section{Weighting of Soil}

Soil in the study are, are sandy clay, sandy clay loam, sandy loam, loamy sand, clay, sand, clayloam, and others (Table 4.23). Nearly $56.5 \%$ of the total area has sandy clay loam. The soil cover in the study area is shallow and varies from a minimum depth of $70 \mathrm{~cm}$ in the proximity of

\begin{tabular}{|l|l|l|l|l|l|l|l|}
\hline SOIL & NPX1 & NPX2 & NPX3 & NPX4 & W+ & W- & C \\
\hline Sandyclayloam & 2053 & 2042 & 423794 & 719366 & 1.3523 & 0.7924 & 0.5599 \\
\hline Loamysand & 69 & 4026 & 6301 & 1136859 & 3.057 & 0.9886 & 2.0684 \\
\hline Clay & 315 & 3780 & 65162 & 1077998 & 1.3495 & 0.9789 & 0.3706 \\
\hline Sandyclay & 521 & 3574 & 142475 & 1000685 & 1.0208 & 0.997 & 0.0238 \\
\hline Sandyloam & 1060 & 3035 & 483941 & 659219 & 0.6115 & 1.2852 & -0.6738 \\
\hline Sand & 0 & 4095 & 77 & 1143083 & 0 & 1.0001 & -1.0001 \\
\hline Clayloam & 0 & 4095 & 15 & 1143145 & 0 & 1.0001 & -1.0001 \\
\hline Others & 77 & 4018 & 21395 & 1121765 & 1.0047 & 0.9999 & 0.0048 \\
\hline
\end{tabular}
Vilpatti to a maximum of $126 \mathrm{~cm}$ in the extreme south-eastern part of the study area near Ayyaraganam. The soil texture represents the relative proportions of sand, silt and clay. The term "texture" refers to the size of the individual soil particles and has nothing to do with the amount of organic matter present in the soil. It has been observed that the soil affects the landslides mainly through these two soil characteristics. High ground water conditions occurring in sandy soils may liquefy the masses resting on the slopes during an earthquake. This can cause a landslide on a slope even as gentle as 10 to 20 percent.

\section{WEIGHTS OF EVIDENCE MODEL}

In this study, the weights-of-evidence modeling was used for the large-scale landslide susceptibility mapping. The weights-of-evidence model has many advantages compared to the other statistical methods. Weights-ofevidence is a data-driven method that is basically the Bayesian approach in a log-linear form using prior and posterior probability and is applied where sufficient data are available to estimate the relative importance of evidential themes by statistical means (Bonham-Carter 1994). The weights of evidence modeling use the Bayesian probability approach and were originally designed for mineral potential assessment (Bonham-Carter, 1988; Bonham-Carter, 1994). This method was also being applied in landslide susceptibility mapping in the past one decade (Lee et al., 2002; Van Westen et al., 2003; Dahal et al., 2008 and Regmi eta al., 2010). If $F$ represents the presence and F represents absence of a potential landslide factor and If $\mathrm{L}$ represents the presence and $\mathrm{L}$ represents absence of landslide, then WoE method calculates the positive and negative weights of the respective factor classes based on the probability ratios (Bonham- Carter, 2002) as follows.

$$
\begin{aligned}
& \mathrm{W}^{+}=\log _{\mathrm{e}}\left(\frac{\mathrm{P}\{\mathrm{F} \mid \mathrm{L}\}}{\mathrm{P}\{\mathrm{F} \mid \overline{\mathrm{L}}\}}\right) \\
& \mathrm{W}^{-}=\log _{\mathrm{e}}\left(\frac{\mathrm{P}\{\overline{\mathrm{F}} \mid \mathrm{L}\}}{\mathrm{P}\{\overline{\mathrm{F}} \mid \overline{\mathrm{L}}\}}\right)
\end{aligned}
$$


For each factor positive weight $(\mathrm{W}+)$ indicates the present of spatial association between conditioning factor $(F)$ and landslides $(\mathrm{L})$ while the magnitude of this weight indicates the positive correlation between the presence of the predictive factor and the landslides. A negative weight (W-) indicates an absence of the spatial association between predictive factor $(F)$ and landslides $(\mathrm{L})$ while the magnitude shows the level of negative correlation.
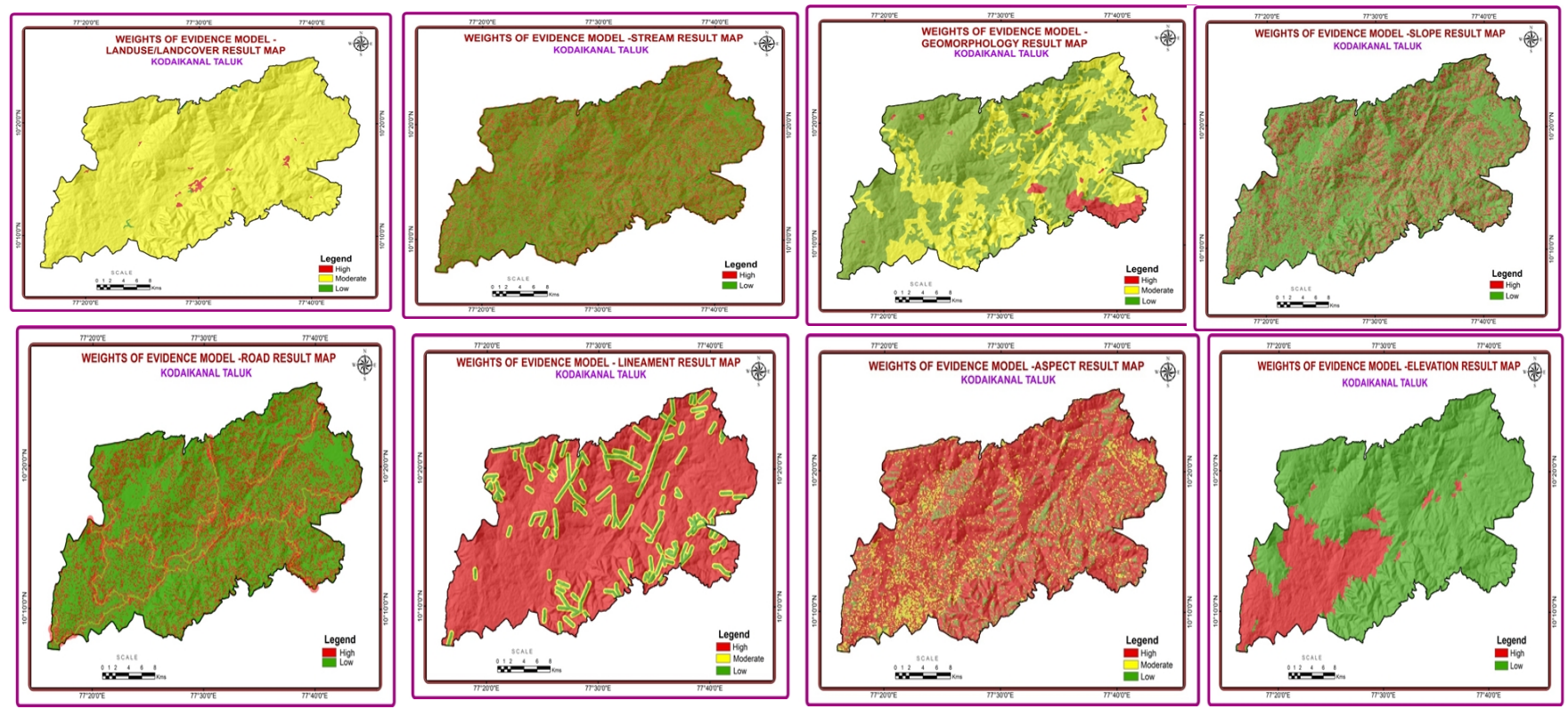

The weight contrast values were assigned to each respective class within each of the predictive factor thematic layers in ArcGIS 10 using "Raster calculator". The resulting weighted raster layers were added together to obtain a raster layer of the landslide susceptibility index

$L S I=W f$ Slope $+W f$ Aspect $+W f$ Elevation $+W f$ Geomorphology $+W f$ Lineament $+W f$ Landcover $+W f$ Drainage + $W f$ Road $+W f$ Soil $+W f$ Rainfall

The result of WoE modeling is a probabilistic map based on evidence of landslides. Weights calculated individually for the ten parameters to produce estimated evidence. Different weights can be summed by using the natural logarithm of odds called log it. In this case the contrast $\mathrm{C}(\mathrm{C}=\mathrm{W}+-\mathrm{W}-)$ gives a measure of spatial association between the predictors and landslides (Yannick Thiery et al.2005). Calculations of values of $\mathrm{W}+$ and $\mathrm{W}$-for all selected variables used to calculate the posterior probability, update the prior probability. When multiple predictors are combined, areas that have a weight higher or lower respectively correspond to a greater or smaller probability of finding the landslides. Local knowledge of the landslide susceptibility in the Kodaikanal taluk suggested ten binary predictor patterns of topography namely, soil, geomorpholgy, slope, aspect, elevation, streams, lineament, road, rainfall and land cover which are useful evidence for predicting landslide vulnerability, each of the landslide-related factors, the weights and contrast were calculated using the weights-of-evidence

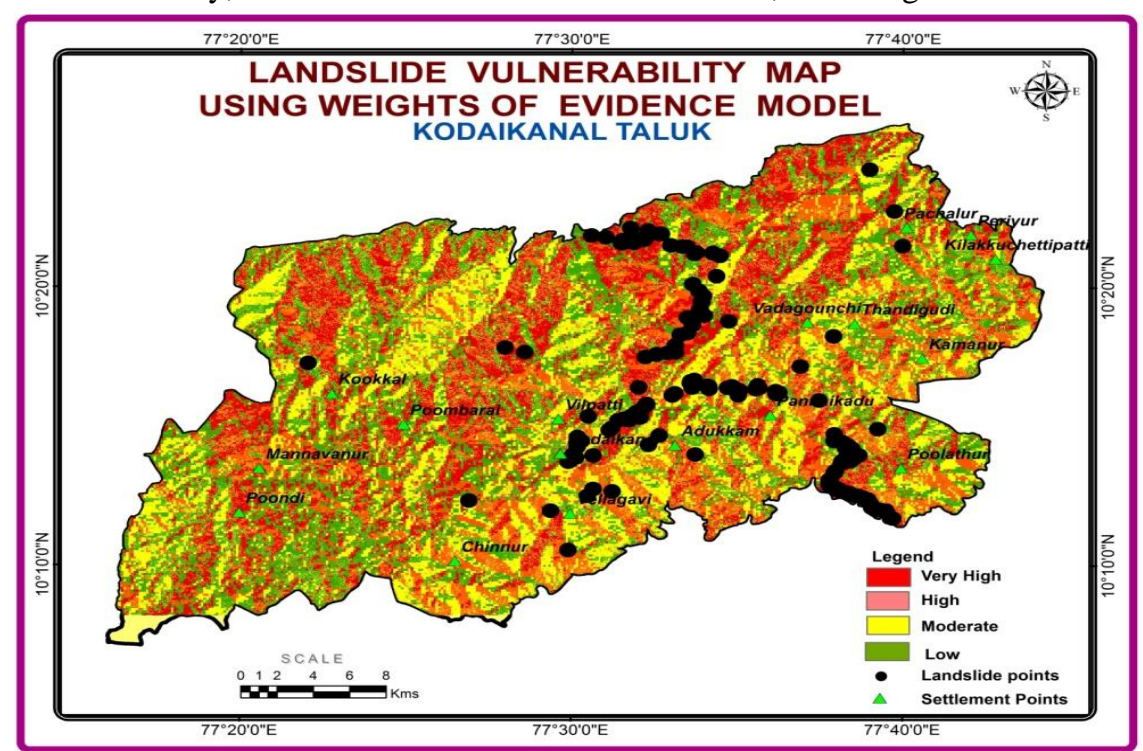
method. The total number of pixels in the study area was 1143160, and the total number of landslide occurrences was 4095 .

All the controlling parameters by giving different weight age value for all the themes, the final LVZ map is prepared and categorized into 'Very High', High, 'Moderate', and 'Low' vulnerability zones. Low $8.3 \%$ of the area which contains $41.4 \%$ of the observed landslides has a high landslide vulnerability $16.9 \%$ of the study area which has $33.9 \%$ of the observed landslides has a high landslide vulnerability. $38.4 \%$ of the study area has a modrate landslide vulnerability which contains $19.8 \%$ of the observed landslides. $6.03 \%$ of the study area which 


\section{Landslide Vulnerability class using Weights of Evidence Model}

\begin{tabular}{|l|l|l|l|l|l|l|}
\hline $\begin{array}{l}\text { Classification } \\
\text { method }\end{array}$ & $\begin{array}{l}\text { Susceptibility } \\
\text { classes }\end{array}$ & $\begin{array}{l}\text { No. of } \\
\text { Area } \\
\text { pixel }\end{array}$ & $\begin{array}{l}\text { No.of } \\
\text { Landslide } \\
\text { Pixel }\end{array}$ & $\begin{array}{l}\text { Area } \\
\text { (Percent) }\end{array}$ & $\begin{array}{l}\text { Landslide } \\
\text { (Percent) }\end{array}$ & $\begin{array}{l}\text { Landslide } \\
\text { Density }\end{array}$ \\
\hline \multirow{3}{*}{$\begin{array}{l}\text { Natural } \\
\text { Break(Jenks) }\end{array}$} & Low & 411975 & 197 & 36.038262 & 4.8107448 & 0.000478184 \\
\cline { 2 - 7 } & Moderate & 442461 & 813 & 38.705081 & 19.85348 & 0.00183745 \\
\cline { 2 - 7 } & High & 193256 & 1696 & 16.90542 & 41.416361 & 0.007187358 \\
\cline { 2 - 7 } & Veryhigh & 95468 & 1389 & 8.3512369 & 33.919414 & 0.017765115 \\
\hline Total & & 1143160 & 4095 & & & \\
\end{tabular}

contains $4.8 \%$ of the observed landslides has a low landslide vulnerability.

\section{ACCURACY ASSESSMENT}

The accuracy of the final LVZ map is evaluated on the basis of the observed landslides. First, the final LVZ map is checked by overlaying with the observed landslide map. 187 of the 213 observed landslides are good predicted, and only 26 of the total landslides are wrongly predicted. The LVZ map with the observed landslides indicating the different levels of prediction.Most of these areas which are situated in Vadakavunji, Adukkam and Perumalmalai have verified conditions of slope, geomorphology and elevation, but some key features are noticeable as, Slope angles are normally higher than $20^{\circ}$, and predominantly, higher than $40^{\circ}$. All wrongly predicted landslides occurred mainly in Pachalur, Periyur. These areas have various unfavourable conditions for landsliding.

\begin{tabular}{|l|l|l|}
\hline \multirow{2}{*}{$\begin{array}{l}\text { Accuracy of } \\
\text { prediction }\end{array}$} & \multicolumn{2}{|l|}{ Observed landslides } \\
\cline { 2 - 3 } & Number & Percentage (\%) \\
\hline Good & 187 & 87.79342723 \\
\hline Wrong & 26 & 12.20657277 \\
\hline Total & 213 & 100 \\
\hline
\end{tabular}

\section{CONCLUSION}

Four different classification methods were used to classify landslide vulnerability index into susceptibility classes; low, moderate, high, and very high. Natural break classification method gave the best result. Sixty percent of the landslides fall closer to the road authenticating the relationship between landslide and proximity to the road. The kodaikanal areas close to road and the erosion of the bank of removal of support is one of the main processes responsible for landslides. Landslides are frequent in areas road sides. Majority of the landslide have occurred close to I order streams and hence, the incipient erosion taking place in the hills is one of the reasons for slope failure.

\section{REFERENCES}

[1] Agterberg F.P., Bonham-Carter G.F., Cheng Q., Wright D.F., (1993), Weights of evidence modeling and eighted logistic regression for mineral potential mapping. In Computers in Geology, 25 Years of Progress, Edited by J. C. Davis, and U. C. Herzfeld (Oxford: Oxford University Press), $13-32$

[2] Agterberg, F.P. and Cheng, Q. (2002 ) "Conditional independence test for weights of evidence modeling”, Natural Resources Research, Vol.11, pp.249-255.

[3] Barredo, J.I., Benavides, A., Hervas, J. and Van Westen C.J. (2000 )“Comparing heuristic landslide hazard assessment techniques using GIS in the Tirajana basin, Gran Canaria Island, Spain”, International Journal of Applied Earth Observation and Geoinformation, Vol.2, No.1, pp.9-23.

[4] Bathrellos G.D., Kalivas D.P., Skilodimou1 H.D. (2009)GIS-based landslide susceptibility mapping modelsapplied to natural and urban planning in Trikala,Central Greece. Estudios Geol., 65(1), 49-65, enero-junio (2009) ISSN: 0367-0449. doi:10.3989/egeol.08642.036

[5] Carrara, A., Pike, R. J., (2008) GIS Technology and Models for Assessing Landslide Hazard and Risk. Geomorphology,94(3-4): 257-260, doi:10.1016/j.geomorph.2008.07.042

[6] Dai, F. C., Lee, C. F., (2002) Landslides on Natural Terrain: Physical Characteristics and Susceptibility Mapping in Hong Kong. Mountain Research and Development, 22(1): 40-47, doi:http://dx.doi.org/10.1659/0276-4741(2002)022[0040:LONT]2.0.CO;2

[7] Ermini L, Filippo C, Casagli N (2005) Artificial neural networks applied to landslide susceptibility assessment. Geomorphology 66:327-343

[8] NRSA (2001) 'Atlas of Landslide Hazard Zonation Mapping in the Himalayas of Uttranchal and Uttar Pradesh states using Remote Sensing and GIS Techniques', Vol. II \& Published by NRSA, Department of Space, Govt. of India

[9] Oh HJ, Lee S, Soedradjat GM (2010) Quantitative landslide susceptibility mapping at Pemalang area, Indonesia. Environ Earth Sci 60:1317-1328

[10] Ohlmacher CG, Davis CJ (2003) Using multiple regression and GIS technology to predict landslide hazard in northeast Kansas, USA. Eng Geol 69:331-343

[11] Van Westen, C. J., Castellanos, E., Kuriakose, S. L., (2008) Spatial Data for Landslide Susceptibility, Hazard, and Vulnerability Assessment: An Overview. Engineering Geology, 102(3-4): 112-131, doi:10.1016/j.enggeo.

[12] Varnes D.J., (1984) Landslide hazard zonation: a review of principles and practice, Review Report: UNESCO Paris, 1-63.

[13] Yiping, H.R. and Beighley, E. (2007) "GIS-based regional landslide susceptibility mapping: a case study in southern California", Earth Surface Processes and Landforms, Vol.33, No.3, pp.380-393

[14] Zezere, J. L., Reis, E., Garcia, R., Oliveira, S., Rodrigues, M. L., Vieira,G. and Ferreira, A. B. (2004) "Integration of spatial and temporal data for the definition of different landslide hazard scenarios in the area north of Lisbon, Portugal", Natural Hazards and Earth System Sciences, Vol.4, pp. 133-146.

[15] Zhou, C.H., Lee, C.F., Li, J. and Xu, Z.W. (2002) "On the spatial relationship between landslides and causative factors on Lantau Island, Hong Kong", Geomorphology, Vol. 43, pp. 197-207, 